\title{
APPROBATION OF MODELS AND LEGISLATION IN ACCOMMODATION INFRASTRUCTURE FOR SOLDIERS FROM LAND FORCES ARMY COMPATIBLE WITH MODELS AND LEGISLATION IN MEMBER STATES OF THE ALLIANCE
}

\author{
Stefan FILIPOV \\ "Vasil Levski" National Military University, Veliko Tarnovo, Bulgaria \\ stefan_filip@abv.bg
}

\begin{abstract}
The membership of the country in the Euro-Atlantic structures, the professionalization of the Armed Forces and their participation in joint operations put the Bulgarian Army in front of the necessity to comply with the rules for communal-household provision applied in the NATO member states. As the resource constraint of the Military Budget, determined by the economic potential of the country, does not allow the construction of new military infrastructure objects, the current models for modernization, maintenance and utilization of the military infrastructure in the part of the communalhousehold provision of the Armed Forces are proposed. The implementation of the presented models is in response to solve problems in improving the maintenance and using military infrastructure elements. On the one hand, the applicability of the models requires the development of scientificallybased norms and legislation for the communal-household provision of the servicemen and on the other hand, it responds to the requirements for improving the quality of life of military personnel in the context of continuous structural reforms and transformations.
\end{abstract}

Keywords: technical requirements, military infrastructure, standard buildings for soldiers, accommodation, Armed Forces

\section{Introduction}

Due to the accession of the Republic of Bulgaria to the Euro-Atlantic structures and in response to the compatibility goals, the efforts of the Bulgarian Defence Agency and the Ministry of Defence, which are related to the maintenance and use of the military infrastructure, are aimed at harmonization with generally accepted norms in the EU and the Alliance member countries. Currently, the requirements for military infrastructure buildings and facilities applied in NATO member states have not been fully enacted and the legal framework does not fully meet the new requirements and norms. Therefore, the presented article appears precisely in response to the important need to adapt them. [1]

\section{Standard Buildings for Soldiers}

Long-term programs have been adopted and are being implemented for the gradual adaptation of the barracks' infrastructure to the requirements of the Armed Forces professionalization in a number of NATO armies in recent years. The plan of the French Army VIVIEN (Valorisation de l'Infrastructure Vie des Engages) is indicative of this. [2] Its main characteristic is its orientation towards improving the living conditions of servicemen in the Army. Its realization aims to motivate people for the military profession and make it more attractive for those entering the 
army system. According to Stefanov, the main objective of the reform of the Armed Forces is their modernisation. In this case, this does not mean that they only get equipped with the latest technologies, materials and weapons, but also have a modern internal organisation aimed at effective execution of core tasks.[8]

It is necessary to consider the issue on the accommodation of soldiers. This is an activity which has a fundamental role on a making quality logistics decisions for strategic, operational and tactical level.[7] The main purpose is to determine the requirements for the residential premises, complying with the norms for communalhousehold provision, designed for the fulfilment of their functional obligations and the requirements for the places for complete recreation. These premises consist of three-person rooms for ground troop soldiers (two-person rooms for corporals and one-person room for junior sergeants), where the areas for recreation and work are clearly distinguished. It is appropriate to use three types of rooms for officers and sergeants, operationally compatible with those of the Alliance, consistent with the national traditions and the economic situation of the country.

It is noteworthy that the VIVIEN plan is a priority for NATO Defence Ministries in the field of infrastructure investment. In these countries, $1 / 4$ of all costs are earmarked for the construction, repair and maintenance of military infrastructure. [2]

A fundamental principle in accommodation of servicemen from the Army of the leading armies of NATO is that the domestic buildings for soldiers are intended for all private soldiers who are passed their initial military training and do not wish or are not permitted to live outside barracks. Soldiers from the Army who are not accommodated in barracks use some amenities in the service zone as wardrobes, bathrooms and more. Regardless of the location of housing, all soldiers have the right to park during the departure on mission. [2]
Providing appropriate conditions is subject to the idea of motivating recruiting young men and women to join the army.[5,6] By means of the maintenance, hygiene and security groups, the amortization and damage to the elements of the military infrastructure is limited and the necessary level of security is achieved. The changes in housing, according to the career development in rank and years of service are a stimulating measure for young ground troop soldier. For example, during the initial military training soldiers of ground troops are accommodated in a room for three (for private soldiers), a room for two (for corporals) and a single room (for junior sergeants). Consideration is also given to the mixed composition of soldiers from Army, so there are separate rooms for men and women. [1]

The proposed changes in housing, depending on career development and seniority, are a stimulating measure for military servants to reach the career growth more quickly.

In the leading armies of the Alliance, good practice is the use of so-called "Standard buildings" for soldiers, sergeants and officers. Considering the interoperability with them, it is appropriate to apply them for accommodation of allied contingents in joint exercises and other cases. This is the reason why the standard buildings should be adapted to the needs of the Bulgarian Army.

The proposed models for accommodating personnel in the required conditions were approved for a mechanized battalion (MB). The choice for this is not accidental. It was taken into account the fact that the MB is general tactical subdivision which is organizationally included in the composition of the Mechanized Brigade (MBR) or Tank Brigade (TBR). For this purpose, as the starting point, we look at the following exemplary MB's staff composition:

- command and control - includes command (4/0/0/4) and HQ

(10/4/10/24); 
- combat units - includes three moto infantry units $(15 / 29 / 225 / 276)$ and a combat support company $(6 / 19 / 82 / \mathbf{1 1 3})$;

- subdivisions for combat support includes Headquarters Company $(6 / 10 / 51 / 73)$;

- serving subdivisions - includes the Technical Equipment Company (3/10/18/32) and the Battalion Medical Unit $(2 / 3 / 9 / 14)$. of which officers - 46; sergeants - 75; and soldiers - 395.

It is necessary to calculate the required squares for the different types of functional units for Room Module, Service Module and External Infrastructure Module to determine the required standard buildings for soldiers of the proposed model for MB's staff composition. The basic data is shown in Table 1.

According to this arrangement a mechanized battalion has 516 staff troops,

Table 1 Parameters of the Different Types of Functional Units of Standard Building for Soldiers

\begin{tabular}{|c|c|c|}
\hline Functional unit & Area & Features / Recommendations / \\
\hline \multicolumn{3}{|r|}{ Room Module } \\
\hline \multirow{3}{*}{ Room } & $42 \mathrm{~m}^{2}$ & - Triple \\
\hline & $21-42 m^{2}$ & - Double \\
\hline & $16-21 m^{2}$ & - Single \\
\hline \multicolumn{3}{|c|}{ Service Module } \\
\hline Laundry Room & $\approx 15 \mathrm{~m}^{2}$ & $\begin{array}{l}\text { - Equipped with } 1 \text { washing machine for every } 20 \\
\text { people and one dryer for every } 3 \text { washing machines. }\end{array}$ \\
\hline $\begin{array}{l}\text { Luggage } \\
\text { compartments }\end{array}$ & $\begin{array}{lr}\text { Set in } & \text { place } \\
\text { according } & \text { to } \\
\text { needs. } & \\
\end{array}$ & $\begin{array}{l}\text { - Located in the attic or in the basement. } \\
\text { - Only users and responsible officials have access to } \\
\text { it. }\end{array}$ \\
\hline Basements & $\begin{array}{lr}\text { Set in } & \text { place } \\
\text { according } & \text { to } \\
\text { needs. } & \end{array}$ & $\begin{array}{l}\text { In addition to the luggage compartments, luggage } \\
\text { storage can be provided in the attic and basement } \\
\text { areas }\left(2 \mathrm{~m}^{2} \text { per person). }\right.\end{array}$ \\
\hline $\begin{array}{l}\text { Household } \\
\text { premises/pantry }\end{array}$ & $\approx 4 \mathrm{~m}^{2}$ & $\begin{array}{l}\text { - Equipped on every floor with a place to pour out } \\
\text { dirty water. }\end{array}$ \\
\hline $\begin{array}{l}\text { Additional } \\
\text { bathroom }\end{array}$ & $\approx 4 \mathrm{~m}^{2}$ & $\begin{array}{l}\text { - Equipped with } 1 \text { wash basin, } 1 \text { toilet, } 1 \text { shower } \\
\text { and a place to pour out waste water. }\end{array}$ \\
\hline \multicolumn{3}{|c|}{ External Infrastructure Module } \\
\hline Entrance hall & $10-25 \mathrm{~m}^{2}$ & $\begin{array}{l}\text { - It consists of a two-chamber hall and a telephone } \\
\text { booth. }\end{array}$ \\
\hline $\begin{array}{l}\text { Bath } \\
\text { disinfection }\end{array}$ & $7-15 m^{2}$ & $\begin{array}{l}\text { - Equipped with } 1 \text { tap for } 20 \text { people. } \\
\text { - Located near the bicycle area. }\end{array}$ \\
\hline Bicycle place & $\begin{array}{l}\text { Determined } \\
\text { locally according } \\
\text { to needs. }\end{array}$ & $\begin{array}{l}\text { - Applies } 0.25 \quad \mathrm{~m}^{2} \quad \text { per person. } \\
\text { - Located near the entrance to the building or inside } \\
\text { it. }\end{array}$ \\
\hline Waste Place & $\approx 10 \mathrm{~m}^{2}$ & $\begin{array}{l}\text { - Possibly located outside the building. } \\
\text { - Separate waste collection could affect the size of } \\
\text { the place. }\end{array}$ \\
\hline Parking & $\begin{array}{l}\text { Determined } \\
\text { locally according } \\
\text { to needs. }\end{array}$ & $\begin{array}{l}\text { - } 1 \text { parking space per room with a size of the } \\
\text { parking spaces }-2.5 \times 5 \mathrm{~m} \text { is required, the number } \\
\text { of which must be in accordance with the local town } \\
\text { plan. }\end{array}$ \\
\hline
\end{tabular}


According to the given parameters of the building, which is $52 \mathrm{~m}$ long and $13 \mathrm{~m}$ wide, the total built-up area is $2028 \mathrm{~m}^{2}$ at $676 \mathrm{~m}^{2}$ per floor.

For the Service Module the required area is:

- laundry room - one of $15 \mathrm{~m}^{2}$ is required;

- basement $-2 \mathrm{~m}^{2}$ is required per soldier, total of $200 \mathrm{~m}^{2}$;

- household premises / pantry /- one of 4 $\mathrm{m}^{2}$ is required;

- additional bathroom - one of $4 \mathrm{~m}^{2}$ is required.

The total required area for the Service Module is $223 \mathrm{~m}^{2}$.

For the External Infrastructure Module the required area is:

- entrance room - one room from $20 \mathrm{~m}^{2}$ is required;
- disinfection bath - one room of $15 \mathrm{~m}^{2}$ is required ;

- place for bicycles $-0.25 \mathrm{~m}^{2}$ per soldier, total one of $25 \mathrm{~m}^{2}$ is required ;

- waste place - one of $10 \mathrm{~m}^{2}$ is required ;

- parking place - $12.5 \mathrm{~m}^{2}$ per room, total $400 \mathrm{~m}^{2}$ is required.

The total required area for External Infrastructure Module is $470 \mathrm{~m}^{2}$.

It should be deducted the area of the Service Module and the elements of the External Infrastructure Module, that are located in the building, from the total builtup area of the separate building which is $2028 \mathrm{~m}^{2}$. Taking into account the thickness of the walls and the area required for stairs, the residential area is approximately 1500 $\mathrm{m}^{2}$ per building.

The number of soldiers by category and subdivisions, shown in Table 2, serves us as a base for the necessary calculations.

Table 2 Distribution of Soldiers by Categories and Subdivisions

\begin{tabular}{|l|r|r|r|r|r|r|r|}
\hline Category & HQ & \multicolumn{1}{|c|}{$\begin{array}{c}\text { Moto } \\
\text { Infantry } \\
\text { Unit }\end{array}$} & $\begin{array}{c}\text { Combat } \\
\text { Support } \\
\text { Company }\end{array}$ & $\begin{array}{c}\text { Headquarters } \\
\text { Company }\end{array}$ & $\begin{array}{c}\text { Technical } \\
\text { Equipment } \\
\text { Company }\end{array}$ & $\begin{array}{c}\text { Battalion } \\
\text { Medical } \\
\text { Unit }\end{array}$ & Total: \\
\hline $\begin{array}{l}\text { Junior } \\
\text { sergeants }\end{array}$ & 1 & 9 & 10 & 3 & 3 & 3 & 29 \\
\hline Corporals & 2 & 24 & 32 & 8 & 8 & 3 & 77 \\
\hline $\begin{array}{l}\text { Private } \\
\text { soldiers }\end{array}$ & 7 & 192 & 40 & 40 & 7 & 3 & 289 \\
\hline Total: & $\mathbf{1 0}$ & $\mathbf{2 2 5}$ & $\mathbf{8 2}$ & $\mathbf{5 1}$ & $\mathbf{1 8}$ & $\mathbf{9}$ & $\mathbf{3 9 5}$ \\
\hline
\end{tabular}

The mathematical modelling for determining the optimal distribution of the number of rooms for accommodated soldiers in Room Module of Standard Building for Soldiers is based on a task of linear programming solved by the Simplex Method.[1] The use of linear optimization to search for opportunities to improve the supply of other services (nutrition) to military units is seen by Glushkov. [3,4]

The most general assignment of the task is as follows:

- there are $m$ different kinds of resources in $b 1, b 2, \ldots, b m$;
- $\mathrm{n}$ different kinds of objects (equipment, constructions, etc.) must be produced.

The quantity of each resource required for the production of each item and its value is known. It is necessary to plan the production (how many pieces of each item to produce) that the value of the output should be maximum.

If Aij denotes the quantity of products from the $i$-th resource required for the production of an object of this type, $\mathrm{Ci}$ - the price of $\mathrm{j}$ the object, $X \mathrm{X}$ - the planned output of $\mathrm{j}$ type, the general formulation of the task is the following: 
$\mathrm{L}(\mathrm{X})=\mathrm{C} 1 \mathrm{X} 1+\mathrm{C} 2 \mathrm{X} 2+$

Subject to the following conditions for the unknown:

$$
\begin{aligned}
& \mathrm{A} 11 \mathrm{X} 1+\mathrm{A} 12 \mathrm{X} 2 \ldots \ldots . \mathrm{A} 1 \mathrm{n} \mathrm{Xn} \leq \mathrm{B} 1 \text {, } \\
& \mathrm{A} 21 \mathrm{X} 1+\mathrm{A} 22 \mathrm{X} 2+\ldots \ldots . . \mathrm{A} 2 \mathrm{n} \mathrm{Xn} \leq \mathrm{B} 2 \text {, } \\
& \mathrm{Am} 1 \mathrm{X} 1+\mathrm{Am} 2 \mathrm{X} 2+\ldots \ldots . \mathrm{Amn} \mathrm{Xn} \leq \mathrm{Bm} \text {, } \\
& \mathrm{Xi} \geq 0, \mathrm{j}=1,2 \text {, } \\
& \text {.n. }
\end{aligned}
$$

Given the above estimates, the total area of a modular room is not appropriate to exceed $1500 \mathrm{~m}^{2}$ per building or $6000 \mathrm{~m} 2$ for the four standard buildings for soldiers. Mathematically, this is an area limitation and has the following:

$\mathrm{X} 1.16+\mathrm{X} 2.21+\mathrm{X} 3.42 \leq 6000$.

Given the accepted status of subdivisions, the following limitations on the number of soldiers by category are adopted:

$\mathrm{X} 1 \leq 29$ - We assume that junior sergeants are $\leq 29$;

$\mathrm{X} 2 \leq 77$ - We assume that the corporals are $\leq 77$

$\mathrm{X} 3 \leq 289-\mathrm{We}$ assume that the private soldiers are $\leq 289$.

The numbers to the unknown X1, X2, X3 represent the number of people who are accommodated in a room of the respective types. The target function is the total number of soldiers that can be accommodated in the four standard buildings. The goal is that this number should be in maximum. The mathematical notation has the form:

$\mathrm{L}(\mathrm{X})=1 . \mathrm{X} 1+2 . \mathrm{X} 2+3 . \mathrm{X} 3 \rightarrow \max$. (2)

Thus, a linear programming task is formulated, taking into account the limit of non-negativity $\mathrm{X} 1 \geq 0, \mathrm{X} 2 \geq 0, \mathrm{X} 3 \geq 0$, and the fact that the solution should be integer.
The task was solved by MS Exsel, whereby the following result was obtained:

$\mathrm{X} 1=29$ rooms of $16 \mathrm{~m}^{2}$ per junior sergeants;

$\mathrm{X} 2=38$ rooms of $21 \mathrm{~m}^{2}$ for corporals;

$\mathrm{X} 3=96$ rooms of $42 \mathrm{~m}^{2}$ for private soldiers.

This result of the optimization model shows that 29 junior sergeants, 76 corporals, and 288 private soldiers can be accommodated, and 1 junior sergeant and 1 private soldier cannot be accommodated. At the same time, the model spends an area of $5294 \mathrm{~m}^{2}$ with a limit of $6000 \mathrm{~m} 2$, which means that 706 $\mathrm{m}^{2}$ will remain unoccupied.

In view of the typography of buildings for soldiers, the number of the standard rooms should be the same. For this purpose we increase the rooms of $16 \mathrm{~m}^{2}$ from 29 to 32 or 8 rooms in the building and the rooms of $21 \mathrm{~m}^{2}$ from 38 to 40 or 10 rooms in a building. With this set-up, all sergeants and corporals are accommodated with one unaccommodated private soldier. At the same time, we have 3 rooms of $16 \mathrm{~m}^{2}$ and 1.5 rooms of $21 \mathrm{~m}^{2}$ not occupied. In this room allocation, the total area is $5384 \mathrm{~m}^{2}$ or unoccupied remain $616 \mathrm{~m}^{2}$. This allows a reduction in the size of the Standard Building for Soldier, but it is expedient for the unoccupied area to be formed in living quarters as well. If it is distributed in rooms of $42 \mathrm{~m}^{2}$, it is possible to accommodate 44 additional soldiers. Together with the vacant rooms, another 50 soldiers can be accommodated. This allows the placement of an enhanced MB or a battalion with larger personnel.

Because of the fact that the standard buildings for soldiers do not provide canteens, the soldiers should be fed in a separate dining room outside of the buildings for accommodation.

The proposed model for buildings for the different categories of soldiers was approbated in order to establish its relevance and applicability. The 
approbation was performed on specific data and indicators for a Mechanized Battalion.

\section{Conclusion}

The proposed option for 4 numbers of Standard Buildings for Soldiers provides accommodation for the entire Military Staff of the mechanized battalion of the Mechanized Brigade and leaving 50 vacancies. This reserve allows accommodating an enhanced battalion or a larger battalion.

The proposed Standard Buildings for Soldiers for accommodating military personnel with these parameters can be used by coalition formations and are operationally compatible with NATO armies. They can also be used to house soldiers from NATO armies in exercises or operations under Article 5 of the Washington Treaty.

\section{References}

[1] Filipov, S., Opportunities for Improving the Maintenance and Use of Military Infrastructure, Dissertation, G. S. Rakovski Academy, Sofia, 2010.

[2] General Directorate of Engineering Troops, Residential Accommodation of Soldiers. Part One. Basic Principles, France, May 2007.

[3] Glushkov, P., A Study of Nutrition and the Nutritional Status of Servicemen, Assessed on the Basis of Anthropometric Indicators, The 23rd International Conference The Knowledge-Based Organization, Conference proceedings 2, Romania, Nicolae Balcescu" Land Forces Academy, Sibiu, 2017, pp. 298-302.

[4] Glushkov, P., Use of Linear Optimization Model in Defining the New Standards for the Preparation of Food for Servicemen in Preparation for Participation in Peacekeeping Operations, The 23rd International Conference The Knowledge-Based Organization, Conference proceedings 2 Romania, Nicolae Balcescu" Land Forces Academy, Sibiu, 2017, pp.65-70.

[5] Petrova, E., Motivation for Education and Learners' Satisfaction with the Choice of Military Specialisation or Civilian Specialty, The $23^{\text {rd }}$ International conference Knowledge-Based Organization, Sibiu, Conference proceedings, Vol. XXIII No 2, 2017, pp. 355-360.

[6] Petrova, E., Specific Subjects of License Academic Program - an Important Stage of Professional Development of Future Military Leaders at the National Military University, Bulgaria, The Annals of Spiru Haret University, Romania, Volume 6, issue 3, 2016, pp.113 $\div 119$.

[7] Stefanov, N., Analysis of Some of the Applicable Outsourcing Services in the Structures of the Bulgarian Armed Forces, International conference Knowledge-Based Organization, Volume XXIII No 1, 2017, pp. 473-478.

[8] Stefanov, N., Analysis of the Use of Outsourcing Services for Maintenance and Repair of the Equipment and Armament Available in the Structures of the Bulgarian Armed Forces, International conference Knowledge-Based Organization, Volume XXIII No 1, 2017, pp. 467-472. 